\title{
The New Nigerian Agricultural Policy: Efficient for Food Security?
}

\author{
Owolabi I.O. ${ }^{1, *}$, Ashaolu J.T. ${ }^{2}$, Twumasi-Ankrah S. ${ }^{3}$ \\ ${ }^{1}$ Department of Agronomy, University of Ilorin, Nigeria \\ ${ }^{2}$ Nutraceutical and Functional Food Research Institute, Prince of Songkla University, Thailand \\ ${ }^{3}$ Department of Mathematics, University of Mines and Technology, Ghana
}

Copyright (C) 2016 by authors, all rights reserved. Authors agree that this article remains permanently open access under the terms of the Creative Commons Attribution License 4.0 International License

\begin{abstract}
The major problem affecting poor people in developing countries has been food insecurity, while households living in poverty have continued to be vulnerable in their situation. Nigeria, being the most populous country in Africa with an urban population growing at an exponential rate, the government's objective of achieving food self-security is a major challenge. The country shows a relatively rapid economic growth, which makes this goal not unrealistic but rather requires a great deal of effort. Having many singular features, it has no exception when it comes to agricultural policy in the region, caught between tremendous potentials, immense ambitions. After the post-colonial era in Nigeria, agricultural policies and programmes have undergone changes and this has been seen to emphasize almost the same objectives like: providing food for the inhabitants of the nation (food security and sufficiency) and export excess to other countries and to provide rural dwellers and farmers with extension services, to mention a few. This study has laid emphasis on the new agricultural policy launched in 2001 which is termed 'new policy' with evaluations made on its influence on some indicators of agricultural production in the country and components of food security. Deductions from the secondary data used show that the new policy in Nigeria has influenced the fore mentioned positively with exceptions on food stability and access to sanitation facilities. Possible causes of decline in effectiveness on these components of food security were identified with recommendations proffered for future policies and programme interventions.
\end{abstract}

Keywords Agricultural Policies, Nigeria, Food Security, Agricultural Production

\section{Introduction}

In 2014, Nigeria was considered as the largest economy in Africa. The agricultural sector employs approximately two-thirds of the country's total labor force ${ }^{[1]}$. The share of agriculture value added to total GDP was $50 \%$ in $2002^{[2]}$. Nigeria is the world's largest producer of cassava, yam, and cowpea; yet it is a food-deficit nation and depends on imports of grains, livestock products, and fish ${ }^{[1]}$. However, it has one of the highest numbers of severely malnourished children in the world. Approximately $24 \%$ of the children under five years old, (which is more than a million children), suffer from malnutrition. An estimated 70 percent of Nigerians live on less than US\$1.25 per day. Nigeria was ranked 40th out of 79 on the 2012 Global Hunger Index and 156th out of 187 on the 2011 UNDP Human Development Index.

Food in-security is identified as a major cause of malnutrition. In northern Nigeria, widespread poverty, volatile food prices, and recurring food shortages have left an estimated 800,000 children at risk of severe malnutrition. This has encouraged the government of Nigeria to work towards food security. Food security is defined as when all the people at all times have physical and economic access to sufficient, safe and nutritious food to meet their dietary needs and food preferences for an active and healthy life ${ }^{[3]}$. Agriculture improves food security in so many ways, fundamentally by increasing the amount of food and also provides means to purchase food. The annual growth rate of food production in the $2007-2012$ periods was $2.18 \%$, but Nigeria's total population grew $2.82 \%$ annually (that is averagely 165.2 million), for the same period. This dis-equilibrium between food production and increasing population will pose a great challenge for Nigeria to achieve food security. Thus, it is obvious that, a lot of people will go hungry in Nigeria.

Again, the beginning of the petroleum boom in the early 1970s had adverse effects on the production levels of both food and cash crops. As food production could not keep pace with its increasing population, Nigeria began to import food. Nigeria's total food and agricultural imports are valued at 
approximately US $\$ 1.6$ billion per year [4].

New strategies are required in order to ensure sustainable food security so that the challenge of feeding a growing population can be addressed [5]. Thus, over the years, several governments have introduced a lot of agricultural policies to help achieve food security in the country. It should be noted that inappropriate agricultural policies can progressively make agricultural work unattractive, which in the long run will worsen food production and other agricultural production.

Accordingly, the purpose of formulating these agricultural policies is to encourage food production and ensure food security. Thus, it is appropriate to evaluate these agricultural policies to know if the purposes of their formulation are achieved. According to [6], Nigeria lunched a new agricultural policy in 2001. In this study, we consider all agricultural policies before 2001 as "old policy" and from 2001 onwards as "new policy". This study seeks to assess the effect of the new agricultural policy on (1) some indicators of agricultural production and (2) food security.

\section{New Agricultural Policy and Food Production}

The focus of this section is to evaluate the effect of Nigeria's new agricultural policy on food production. The previous agricultural policy document was finalized in 1998 and was supposed to remain operative until the year 2000 . A new agricultural policy document was launched in 2001 [6]. We have indicated earlier that, all agricultural policies before 2001 are considered as "old policy" and from 2001 onwards as "new policy".

The objectives of the new agricultural policy are: (i) the achievement of self-sufficiency in basic food supply and the attainment of food security; (ii) increased production of agricultural raw materials for industries; (iii) increased production and processing of export crops, using improved production and processing technologies; (iv) generating gainful employment; (v) rational utilization of agricultural resources, improved protection of agricultural land resources from drought, desert encroachment, soil erosion and flood, and the general preservation of the environment for the sustainability of agricultural production; (vi) promotion of the increased application of modern technology to agricultural production; and, (vii) improvement in the quality of life of rural dwellers.

Generally, the policy aims at stimulating agricultural production for domestic market, agricultural input demand by farmers, domestic agricultural commodity trade, agricultural input supply to farmers and domestic investment in agriculture. Thus, we expect that, this new agricultural policy can have a positive effect on agricultural food production. In Table 1, crop production per hectare of land increased from 1997 to 2012; that is crop production increased irrespective of which agricultural policy was in force. However, the annual growth rate of crop production value per hectare was much higher in the new policy than during the old policy. Thus, the new agricultural policy has positively contributed to crop production per hectare of land in use.

According to Table 2, the total agricultural production improved under the new policy.

In specific, there was about $20 \%$ improvement in the annual growth rate of agriculture production under the new policy. Also, in migrating from the old policy to the new policy, food production increased widely. It is obvious that, these agriculture indicators have greatly improved under the new policy.

In Table 3, the quantity of wheat increased in the two periods of the old policy but we observed more than triple increased in the second period of the new policy. Generally, production quantities improved under the new policy as compared to the old policy. However, there was a decline in production quantities in the second period (2011) of the new policy. Also, production quantities for other selected commodities increased after the formulation of the new policy (i.e from 2000-2006) and thereafter decreases.

Table 1. Crop production value per hectare in Nigeria

\begin{tabular}{|c|c|c|c|c|c|c|}
\hline & \multicolumn{2}{|c|}{ Old Policy } & \multicolumn{2}{|c|}{ New Policy } & \multicolumn{3}{|c|}{ Annual growth rate [\%] } \\
\hline & 1997 & 2000 & 2007 & 2012 & $1997-2000$ & $2007-2012$ \\
\hline Crop production per ha of land in use (\$) & 594 & 658 & 709 & 814 & 2.07 & 2.8 \\
\hline
\end{tabular}

Sources: FAOSTAT, FAO of the UN, Accessed on February 4, 2015. http://faostat.fao.org/site/612/default.aspx\#ancor - FAOSTAT, FAO of the UN, Accessed on August 12, 2014. http://faostat.fao.org/site/377/default.aspx\#ancor

Table 2. The value of total agriculture production and food production (tonnes) in Nigeria

\begin{tabular}{|c|c|c|c|}
\hline & \multicolumn{2}{|c|}{ Old Policy } & \multicolumn{2}{c|}{ New Policy } \\
\hline & 1997 & 2000 & 2007 \\
\hline Total agricultural production & 25291 & 29562 & 34054 \\
\hline Food production & 24948 & 29188 & 33637 \\
\hline Source: FAOSTAT, FAO of the UN, Accessed on February 4, 2015. http://faostat.fao.org/site/612/default.aspx\#ancor
\end{tabular}


Table 3. Production quantities for selected commodities (tonnes) in Nigeria

\begin{tabular}{ccccc}
\hline & \multicolumn{2}{c}{ Old Policy } & & New Policy \\
\hline Wheat & $\mathbf{1 9 9 6}$ & $\mathbf{2 0 0 0}$ & $\mathbf{2 0 0 6}$ & $\mathbf{2 0 1 1}$ \\
Cereals & 47,000 & 73,000 & 71,000 & 165,000 \\
Oilcrops & $21,665,000$ & $21,370,000$ & $28,864,000$ & $20,702,585$ \\
Meat & $2,032,987$ & $2,399,169$ & $3,491,454$ & $2,777,236$ \\
Coarse grain & 952,014 & $1,053,124$ & $1,199,426$ & $1,058,736$ \\
Paddy rice & $18,496,000$ & $17,999,000$ & $24,751,000$ & $15,924,971$ \\
Coffee & $3,122,000$ & $3,298,000$ & $4,042,000$ & $4,612,614$ \\
Cocoa beans & 3,780 & 3,830 & 5,340 & 2,600 \\
\hline
\end{tabular}

Source: FAOSTAT, FAO of the UN, Accessed on February 4, 2015. http://faostat.fao.org/site/567/default.aspx\#ancor

It is obvious that, agricultural production improved as we migrate from the old policy to the new policy. Thus, the new policy has a positive impact on agricultural production in Nigeria.

\section{Food Security and New Policy}

The four components of food security are: (i) food availability: sufficient qualities of food availability on a consistent bases; (ii) food access: having sufficient resources to obtain appropriate foods for a nutritious diet; (iii) food use: appropriate use based on knowledge of basic nutrition and care; (iv) stability in food availability, access and utilization ${ }^{[3,7]}$. In this section, we evaluate the effect of the new agricultural policy on food security by considering these components.

\section{The Four Main Components of Food Security}

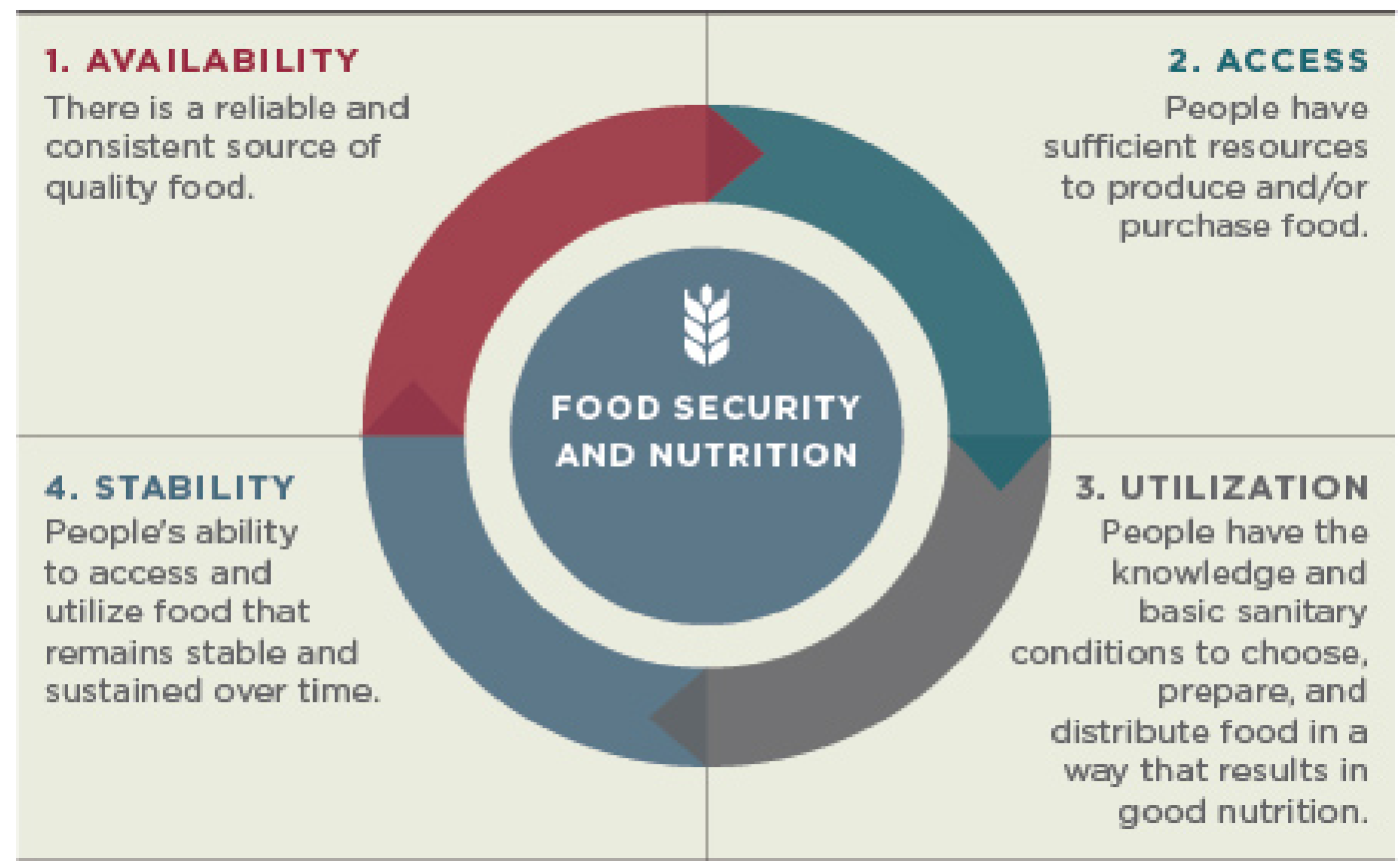

Source: www.counterpart.org

Figure 1. Components of food security

Five items constitute the availability aspect of food security. In Table 4, there is an improvement in all the items under the new agricultural policy, with the exception of share of dietary energy supply (derived from cereals, roots and tubers). Thus, the new agricultural policy has contributed to the improvement of the availability of food security in Nigeria. 
Table 4. Items under the availability component of food security

\begin{tabular}{|c|c|c|}
\hline Availability & $\begin{array}{c}\text { Old Policy } \\
(1990-2000)\end{array}$ & $\begin{array}{c}\text { New Policy } \\
(2001-2010)\end{array}$ \\
\hline Average dietary energy supply adequacy (\%) & 117.2 & 123.9 \\
\hline Average value of food production(1\$/caput) & 186.9 & 211.5 \\
\hline Share of dietary energy supply derived from cereals, roots and tubers (\%) & 67 & 63.7 \\
\hline Average protein supply (gr/capita/day) & 54.2 & 61.4 \\
\hline Average supply of protein of animal origin (gr/capita/day) & 7 & 9 \\
\hline
\end{tabular}

Source: FAOSTAT, FAO of the UN, Accessed on February 4, 2015. http://faostat.fao.org/site/567/default.aspx\#ancor

Under the new agricultural policy, access to food security has improved. There are drastic decline in depth of food deficit and prevalence of food inadequacy, which is good indication. This has contributed to a drastic decline of the prevalence of undernourishment from 13.8 to 7.4. Generally, access to food security has improved under the new agricultural policy.

Table 5. Items under the accessibility component of food security

\begin{tabular}{ccc}
\hline Access & Old Policy & New Policy \\
$(1990-2000)$ & $2001-2010)$ \\
\hline Road density (per 100 square Km of area of land) & 18.2 & 20 \\
Rail lines density (per 100 square Km of area of land) & 0.3 & 0.4 \\
Gross domestic product per capita (in purchasing power equivalent) (Int.\$) & 2863.791 & 4100.3 \\
Domestic food price index (Index) & 2.3 & 2.4 \\
Prevalence of undernourishment (\%) & 13.8 & 7.4 \\
Depth of the food deficit (Kcal/capita/day) & 89.2 & 45.6 \\
Prevalence of food inadequacy (\%) & 20.5 & 12.4 \\
\hline
\end{tabular}

Source: FAOSTAT, FAO of the UN, Accessed on February 4, 2015. http://faostat.fao.org/site/567/default.aspx\#ancor

In Table 6, the stability of food security under the new agricultural policy has not been all that encouraging. It is obvious that, cereal import dependency ratio increased from 6.4 in the old policy to 15.5 in the new agricultural policy. Domestic food price volatility and food production variability increased under the new agricultural policy.

Table 6. Items under the stability component of food security

\begin{tabular}{ccc}
\hline Stability & $\begin{array}{c}\text { Old Policy } \\
(1990-2000)\end{array}$ & $\begin{array}{c}\text { New Policy } \\
(2001-2010)\end{array}$ \\
\hline Cereal import dependency ratio (\%) & 6.4 & 15.5 \\
Percent of arable land equipped for irrigation (\%) & 0.7 & 0.8 \\
Political stability and absence of violence/terrorism (\%) & -1.1 & -1.8 \\
Domestic food price volatility (Index) & 11.5 & 14.3 \\
Per capita food production variability (Int. \$ per capita) & 4.4 & 7.2 \\
Per capita food supply variability (Kcal/capita/day) & 47.1 & 30.4 \\
\hline
\end{tabular}

Source: FAOSTAT, FAO of the UN, Accessed on February 4, 2015. http://faostat.fao.org/site/567/default.aspx\#ancor

In Table 7, access to improved water sources increased under the new agricultural policy. However, access to improved sanitation facilities declined under the new policy. Government has to focus on improving access to sanitation facilities. This is not a good indication for food security. Under the new policy, there is a considerable decline of the percentage of children under 5 years of age affected by wasting and who are stunted and underweight.

Table 7. Items under the utilization component of food security

\begin{tabular}{ccc}
\hline Utilization & Old Policy \\
$(1990-2000)$ & $\begin{array}{c}\text { New Policy } \\
(2001-2010)\end{array}$ \\
Access to improved water sources (\%) & 50 & 59.3 \\
Access to improved sanitation facilities (\%) & 35 & 30.3 \\
Percentage of children under 5 years of age affected by wasting & 16.7 & 13 \\
Percentage of children under 5 years of age who are stunted & 44.7 & 42.3 \\
Percentage of children under 5 years of age who are underweight & 32.5 & 26.5 \\
Prevalence of anaemia among pregnant women (\%) & 61.7 & 60 \\
Prevalence of anaemia among children under 5 years of age (\%) & 76.8 & 74 \\
\hline
\end{tabular}

Source: FAOSTAT, FAO of the UN, Accessed on February 4, 2015. http://faostat.fao.org/site/567/default.aspx\#ancor 
Table 8. Imports of agricultural products in Nigerian, 1990-2013 (Million dollars and percentage)

\begin{tabular}{|c|c|c|c|c|c|c|c|}
\hline Ta & \multicolumn{2}{|c|}{$\begin{array}{c}\text { Value } \\
\text { (Old policy) }\end{array}$} & \multicolumn{3}{|c|}{$\begin{array}{c}\text { Value } \\
\text { (Old policy) }\end{array}$} & \multicolumn{2}{c|}{$\begin{array}{c}\text { Share in economy's total } \\
\text { merchandise imports }\end{array}$} \\
\hline Country & $\mathbf{1 9 9 0}$ & $\mathbf{2 0 0 0}$ & $\mathbf{2 0 1 1}$ & $\mathbf{2 0 1 2}$ & $\mathbf{2 0 1 3}$ & $\mathbf{2 0 0 5}$ & $\mathbf{2 0 1 3 a}$ \\
\hline Nigeria d & 658 & 1212 & 6180 & 5628 & 6180 & 14.3 & 11.0 \\
\hline
\end{tabular}

d Includes Secretariat estimates

A Or nearest year

Source: World Trade Organization. International Trade Statistics 2014 www.wto.org/statistics. Accessed November 19, 2015

In table 8 , the value of imports of agricultural products of Nigerian economy increased from 1990-2000 during the old policy and when migrating from the old policy to the new one, the value rose greatly ( $>5$ folds). This shows that during the new policy, more agricultural products were made available thereby enhancing food availability which is a principal component of food security.

\section{Re-assessing the New Policy}

There are several stakeholders to which the new agricultural policy has spelt out definite roles and responsibilities and these include the federal government, state government, local governments as well as the private sector so as to remove role duplication and overlapping functions among them. These stakeholders have assessed and came up with several perspectives on the effectiveness of policies, regulations and institutions on Nigeria's agriculture. In other words, policies were sought from policy makers and implementers.

Generally, those policies aimed at stimulating on-farm production rank highest. These include those policies aimed at stimulating agricultural production for domestic market, agricultural input demand by farmers, domestic agricultural commodity trade, agricultural input supply to farmers and domestic investment in agriculture. From the ranking, it is evident that the more effective policies and regulations are those targeted to upstream agricultural production activities and geared towards the domestic market. Policies geared towards enhanced post-production activities such as commodity storage, commodity processing, transportation and distribution services as well as commercialization of agriculture are generally ranked low as evaluated by the Nigerian Investment Promotion Commission. Little wonder in spite of abundance of food production, hunger still does exist among the populace in excess, with both under- and malnutrition still coexisting with apparent plentiful supply of food. From the preceding facts, the current policy is seen to be more effective in the primary production subsector of agriculture than in the downstream subsector. Impact of policies on the welfare status of the people and on the environment remains weak. The thrust of the effective policies generally centers on food self-sufficiency as the policy have more bearing on boosting agricultural production for food self-sufficiency (NIPC, 2003).

Nigeria's agricultural policy tends to have limitations to which is a general lack of coherence, issues of programmes continuity, and issues in relation to their sectoral policies and implementation issues at various institutional levels. These policies were for a long time optimistic and not coordinated among each other with successes, failures and lessons learned in preceding programmes not analyzed. Strategies are not transposed into actions, there is absence of indicators which makes it hard to track and evaluate policy implementation. Finally, the responsibility shared between the federal, state and local governments do not appear to be optimal, either in terms of areas of intervention or resources allocated. Many observers deplore that agricultural policy is elaborated from the top down, with little stakeholder's participation and generally, agricultural programmes managed by states seem to be more effective than federal programmes ${ }^{[5]}$.

\section{Conclusions/ Recommendations}

In this study, we have evaluated the impact of Nigeria's new agricultural policy on food production and food security. A new agricultural policy document was launched in 2001 (NIPC, 2003) ${ }^{[6]}$. Thus, we considered all Nigeria's agricultural policies before 2001 as "old policy" and after 2001 as "new policy. We observed that the new policy has a positive impact on agricultural production in Nigeria as well as on the components of food security discussed in this study. However, the stability of food security and access to improved sanitation facilities declined under the new policy which is not a good indication for food security. Factors responsible for ineffectiveness of the new policy on these could be due to; (i) instability of political climate (ii) insecurity of investments (iii) non-competitive nature of agricultural products from the country in the export market due to high cost of production and lack of adequate processing facilities and (iv) non-standardized product quality.

It could therefore be recommended that government and stakeholders of the new policy should work towards availability of improved technology that sees to stabilizing agricultural production, efficient dissemination of information by the ADPs about availability and importance of the sanitary facilities available and provision of secure tenure and access to land as competition for land has increased during urbanization and large-scale acquisition of land by government. Increasing investment and extension for irrigation facilities, including water harvesting and precision drip system, targeted at market-oriented, younger 
and educated farmers will also increase the stability component food security.

\section{REFERENCES}

[1] IFAD, International Fund for Agricultural Development. West and Central Africa Division Portfolio Performance Report. June 2011- June 2012. Accessed 30/09/2015.

[2] World Bank, 2012. World Bank Development Indicators. [Online]. Available: http://data.worldbank.org. Accessed on $04 / 10 / 2015$

[3] CFS, Coming to Terms with Terminology: Food security, Nutrition security, Food security and nutrition, Food and nutrition security, Committee on World Food Security (CFS), Thirty-ninth Session, Rome, 15-20 October 2012.
[4] Godfray, H., Ch. J., Crute, I. R., Haddad, L., Lawrence, D., Muir, J. F., Nisbett, N., Pretty, J., Robinson, Sh., Toulmin, C. and Whiteley R. (2010). "The future of the global food system," Phil. Trans. R. Soc. September 27, 2010, 365: 2769-2777.

[5] Http://www.inter-reseaux.org $>$ RevueGrainde Sel $>51$ : special issues: Nigeria. Accessed 11/03/2015.

[6] NIPC (Nigerian Investment Promotion Commission) (2003). Agriculture sector profile. Unpublished. http://www.nipc.gov.ng/important $\% 20$ document/The\%20Ne w\%20Nigerian\%20Agricultural\%20Policy.doc. Accessed $11 / 03 / 2015$.

[7] UN-HLTF, Food and Nutrition Security: Comprehensive Framework for Action. Summary of the Updated Comprehensive Framework for Action (UCFA), United Nations System High Level Task Force on Global Food Security (HLTF); Rome/Genève/New York, 2011. Http:www. Monster.ca Accessed 12/03/2015. 